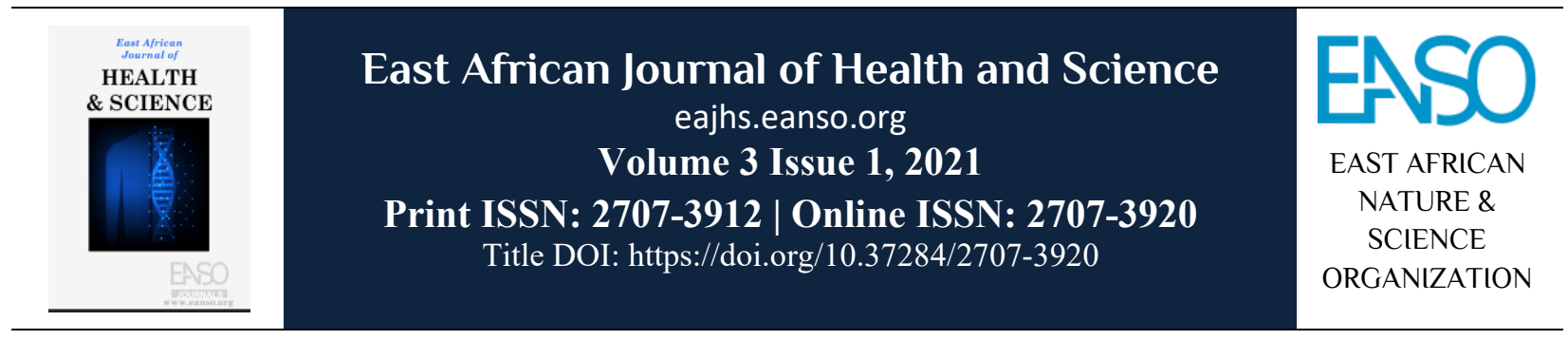

Original Article

\title{
Survey of Some Medicinal Plants Employed for Managing Diabetes Mellitus in Hadejia Town, Nigeria
}

\author{
Mujaheed Abubakar ${ }^{*}{ }^{1}$, Hassan Abdullahi', Zakariya Ali Muhammad ${ }^{1}$, Abdulrazak Mohammed \\ Hussein $^{l}$ \& Abdulkahar Lawal ${ }^{1}$ \\ ${ }^{1}$ Department of Biological Sciences, Sule Lamido University, Kafin Hausa, P. M. B. 048, Nigeria. \\ *Author for correspondence email: mujaheedabubakar88@gmail.com or mujaheed.abubakar@slu.edu.ng.
}

Article DOI: https://doi.org/10.37284/eajhs.3.1.273

\section{Date Published: ABSTRACT}

19 February 2021 Diabetes is a widely spread disorder that disturbs humans in the underdeveloped as well as the developed countries worldwide. The figure of those people suffering

Keywords: from the disease is shooting up specifically in Nigeria. A study of traditional plant Diabetes mellitus, Medicinal Plants, Managing, Hadejia. management of Diabetes Mellitus (DM) in Hadejia town, Jigawa state, Nigeria. Formal meetings were organised to document details about the medicinal plants used in the treatment of DM and their topical names, methods of preparation/administration, plant parts in use, and the demographic characteristics of the interviewees in the study. Sixty (60) participants were interviewed, of which $45 \%$ were within the age group of $31-40$ years, $38.3 \%$ were within the age group of 41-50 years, while 10\% were within the age group of 51-60 years. Most of the participants were married (91.6\%), male (71.6\%), farmers $(23.3 \%)$ and traditional medicine practitioners $(26.6 \%)$. Further, half $(50 \%)$ of the participants were attending Islamic schools; some were not having a formal education with a percentage of (33.3\%). Also, fifteen (15) plants which belong to 12 families were documented as being used for the management of DM in Hadejia town. The families Amaryllidaceae, Fabaceae, Myrtaceae, and Combretaceae, were the highly pronounced families in this research, while leaves, stem bark, and roots were the most commonly used plant parts. A high level of consensus was observed (0.67) among the participants. This work was carried out in order to provide background data on the herbal plants in use traditionally for the management of DM in the study area. 


\section{APA CITATION}

Abubakar, M., Abdullahi, H., Muhammad, Z., Hussein, A., \& Lawal, A. (2021). Survey of Some Medicinal Plants Employed for Managing Diabetes Mellitus in Hadejia Town, Nigeria. East African Journal of Health and Science, 3(1), 12-19. https://doi.org/10.37284/eajhs.3.1.273.

\section{CHICAGO CITATION}

Abubakar, Mujaheed, Hassan Abdullahi, Zakariya Muhammad, Abdulrazak Hussein, and Abdulkahar Lawal. 2021. "Survey of Some Medicinal Plants Employed for Managing Diabetes Mellitus in Hadejia Town, Nigeria". East African Journal of Health and Science 2 (1), 12-19. https://doi.org/10.37284/eajhs.3.1.273.

\section{HARVARD CITATION}

Abubakar, M., Abdullahi, H., Muhammad, Z., Hussein, A. and Lawal, A. (2021) "Survey of Some Medicinal Plants Employed for Managing Diabetes Mellitus in Hadejia Town, Nigeria", East African Journal of Health and Science, 3(1), pp. 12-19. doi: 10.37284/eajhs.3.1.273.

\section{IEEE CITATION}

M. Abubakar, H. Abdullahi, Z. Muhammad, A. Hussein and A. Lawal, "Survey of Some Medicinal Plants Employed for Managing Diabetes Mellitus in Hadejia Town, Nigeria”, EAJHS, vol. 3, no. 1, pp. 12-19, Nov. 2021.

\section{MLA CITATION}

Abubakar, Mujaheed, Hassan Abdullahi, Zakariya Muhammad, Abdulrazak Hussein, and Abdulkahar Lawal. "Survey of Some Medicinal Plants Employed for Managing Diabetes Mellitus in Hadejia Town, Nigeria". East African Journal of Health and Science, Vol. 3, no. 1, Feb. 2021, pp. 12-19, doi:10.37284/eajhs.3.1.273.

\section{INTRODUCTION}

From the early stages of human civilisation, mankind has been using medicinal plants for its healing power. Nature has been a source of medicinal agents for several years whereby quiet a number of modern drugs have been isolated from natural sources (Wais et al., 2012). Many of these isolations were based on the uses of the agents in traditional medicine. Traditional medicine sourced from plants continues to play a vital role in healthcare with the majority of the world's inhabitants relying solely on traditional medicines for their principal health care (Khan et al., 2014). In the presence of the planetary flow of drug resistance, increasing costs of synthetic products, adverse effects and toxicity, products from traditional medicine continue to play a major role in the lives of people worldwide (Jouad et al., 1998).

In Africa, specifically Nigeria, a large number of plants medicinal features were revealed and were adopted in the management of numerous ailments (Modak et al., 2007). Majority of these natural plants are used as seasonings, food, and for medicinal reasons (Nwaogu et al., 2007). Nevertheless, the general understanding of plants by the topical people paves the way as comprehended by the community of a specific ethnic group, because facts about a specific plant differ from both ethnic groups (Wais et al., 2012).

Diabetes mellitus is characterised by interruptions in the major metabolic pathways which results in abysmal blood glucose (sugar) that could lead to intense conditions (Rang et al., 1991). Further, it is a disorder of metabolism as a result of obliteration in insulin-producing $\beta$ cells in the pancreas for type I diabetes while the body muscle and the liver cells sensitivity to insulin action will drastically decrease for type II diabetes (Oyedemi et al., 2009). The International Diabetes Federation has estimated that the number of people with diabetes is expected to rise from 415 million in 2015 to 642 million by 2040 if no urgent action is taken (IDF, 2015). The major challenges to the management of diabetes mellitus are diverse and formidable, as well as the conventional drugs available for its management in the health care system are expensive (Nwaogu et al., 2007). Modern drugs are extensively used in the control of diabetes mellitus, but in return various problems such as ineffectiveness, side effects have also been noticed with the drugs used in the management of diabetes mellitus (Sefidkon et al., 2012).

In Africa, communities with the highest number of diabetes cases were reported from Nigeria with approximately 3.9 million people affected (IDF, 2013). Traditional medicinal plants with their 
various biological constituents have been used effectively by communities for a long time to treat diseases. Currently, specifically in rural settlements in which quite a number of people lack access to advanced antidiabetic drugs, medicinal plants proceeds to play a vital role in the management of diabetes mellitus (Ajaiyeoba et al., 2006). Consequently, this study was carried out to conduct a survey on traditional plants medically in use in the control of diabetes mellitus in Hadejia town.

\section{MATERIALS AND METHODS}

\section{Study Area}

The study was carried out at Hadejia LGA, Latitude $12^{\circ} 27^{\prime} \mathrm{N}$ and Longitude $10^{\circ} 2^{\prime} \mathrm{E}$ Jigawa State, Nigeria. It has a land area of $305 \mathrm{~km}^{2}$ and a population of 105,698 according to the 2006 census by the National Population Commission. The predominant occupations of the inhabitants of the study area are farming, hunting and trading. The area has both wet and dry seasons that range from June - September and from October - May respectively.

\section{Figure 1: Map of the study area}

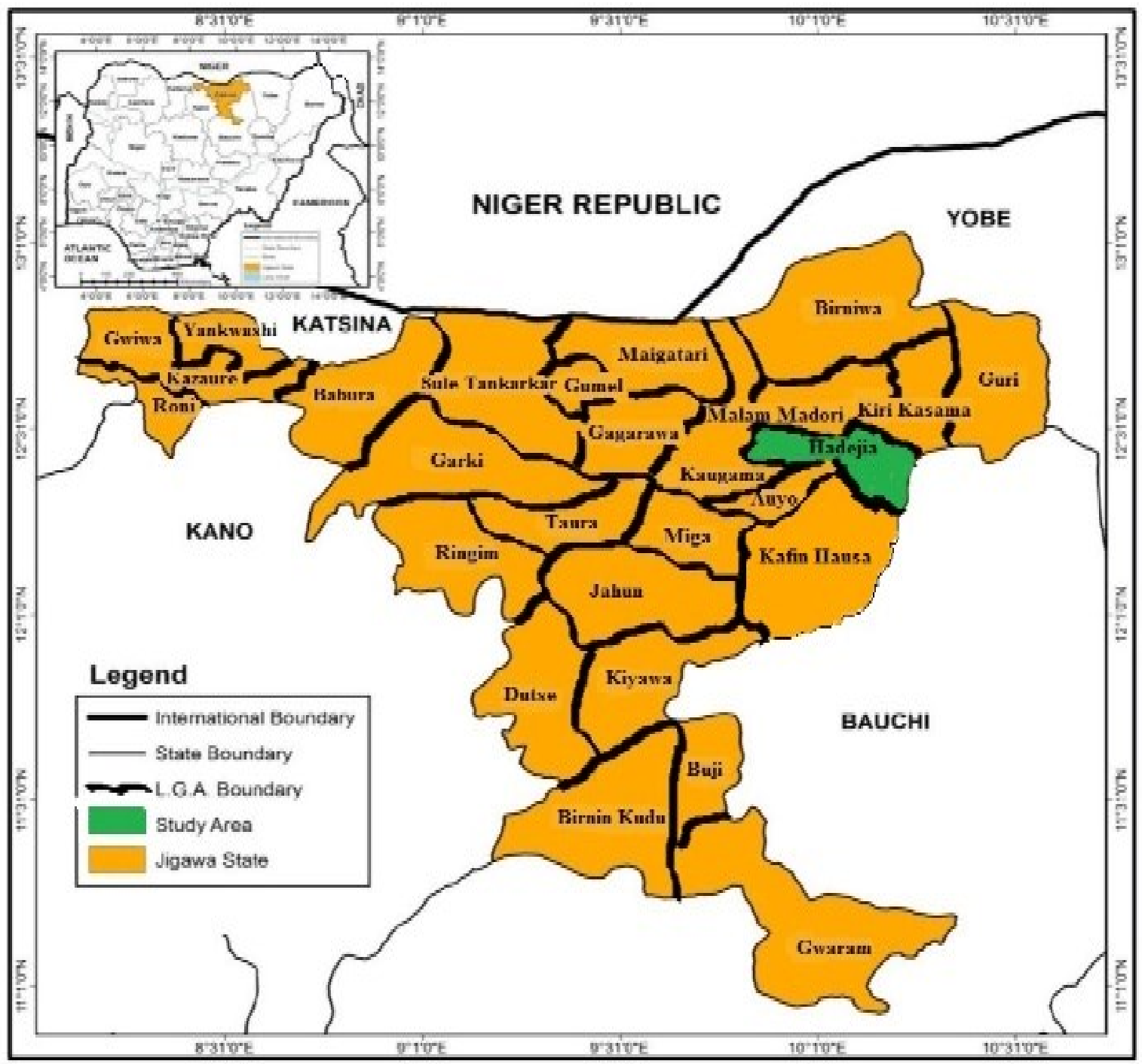




\section{Sample Population}

Purposive sampling technique was used in sampling the population for study (Bitrus et al., 2016). Respondents were comprised of Traditional Medicine Practitioners (TMP's), Herbalists, farmers, nomads, and traditional birth attendants and grouped into different age groups without gender discrimination.

\section{Data Collection}

Relevant authorities as well as individual respondents were contacted for permission prior to the commencement of the study. Semi-structured questionnaires by oral interview employing the local language (Hausa) was used in collecting the data. With the help of Dr Mu'azu Kudan, Department of languages, Hausa unit, Sule Lamido University Kafin Hausa, the questionnaires were translated to Hausa and used for the data collection and then back-translated to English after data collection. Questionnaires were filled by the interviewer and direct questions were avoided. Confirmation of the information given by the respondents was made by making one more visit after the first visit.

\section{Plant Collection and Identification}

Respondents were made to collect the plant species to avoid errors due to variation in local names. Standard identification guides and monographs were employed for specie identification.

\section{Data Analysis}

Data generated were presented using frequencies and percentages. Results on medicinal plant knowledge were analysed using informant consensus factor (ICF) measure. The ICF was calculated using the relation: ICF $=\frac{\left(n_{u r}-n_{t}\right.}{n_{u r}-1}$ (Mesfin et al., 2009), where $n_{u r}$ is the number of citations for each particular ailment and $n_{t}$ is the number of species reported to cure that ailment.

\section{RESULTS AND DISCUSSION}

In this study, 60 respondents were encountered. Among the respondents, the majority were older (Figure 2). This clearly indicates a wide margin between older generation and the younger generation in terms of traditional medicine knowledge. This finding agrees with the reports of Bussmann \& Sharon, (2006), Musa et al., (2011), Mahwasane et al., (2013), Ayeni \& Aliyu (2018).

Figure 2: Age characteristics of respondents and the use of medicinal plants

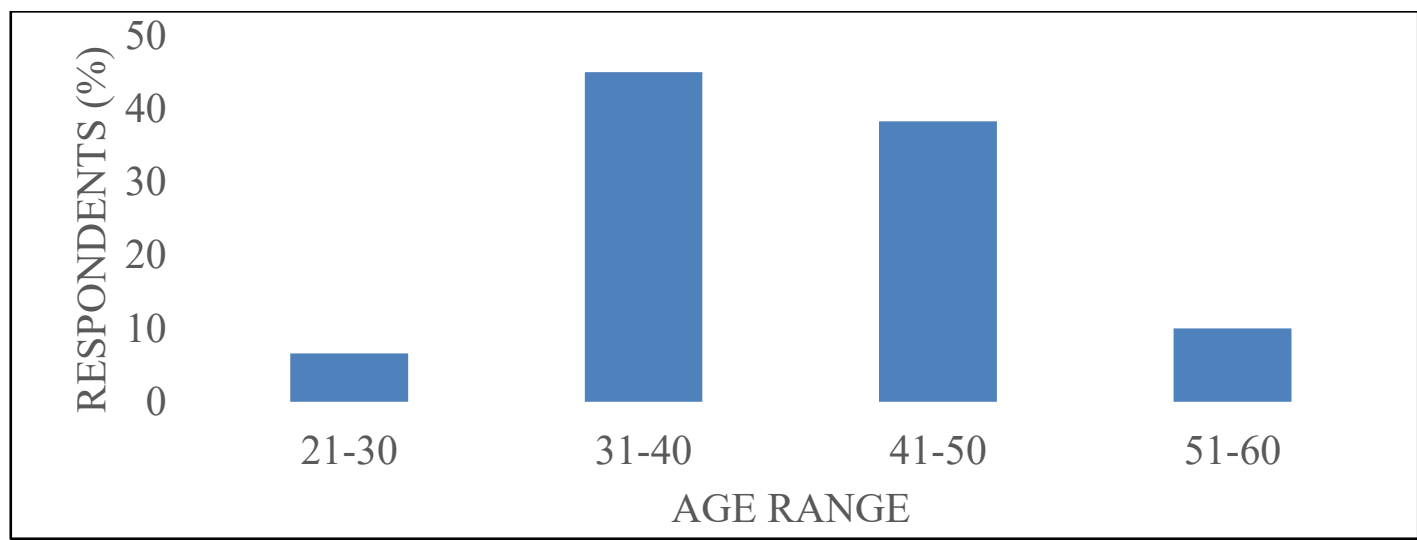

Also, among the respondents, the male counterpart (43, 71.7\%) had the highest number of representation compared to the female counterpart $(17,28.3 \%)$. It is generally believed that awareness on practices involved in traditional medicine are usually transferred to first born sons in the family.
This could be the reason why in this study, the male respondents were more than the female respondents (Zakariya, A. M., Personal communication). This finding agrees with the report of Debella et al., (1999), Addis et al., (2002), Crump et al., (2004). 
In terms of occupation of the respondents, traditional medicine practitioners (TMPs) comprised (26.6\%) of all the respondents and was closely followed by farmers with (23.6\%) respondents. Nomads $(11.6 \%)$ comprised the least among the respondents (Table 1). The high percentage recorded for TMPs can be associated with their dominance in the community and the free will to share their knowledge. The educational status of the respondents saw a majority of them (33.3\%) not having any form of education, this could be associated with socio-cultural perception of education in the community (Table 1).

Table 1: Occupational and education representation of respondents in Hadejia town

\begin{tabular}{llll}
\hline & & $\mathbf{n}$ & $\mathbf{\%}$ \\
\hline Occupation & Traditional medicine practitioners & 16 & 26.6 \\
& Famers & 14 & 23.3 \\
& Herbalists & 13 & 21.6 \\
& Traditional birth attendants & 10 & 16.6 \\
& Nomads & 7 & 11.6 \\
& & 0 & \\
& No formal education & 20 & 33.3 \\
& Primary School & 10 & 16.6 \\
& Secondary School & 0 & 0 \\
& Tertiary institution & 0 & 0 \\
& Islamic & 30 & 50 \\
\hline
\end{tabular}

Fifteen (15) medicinal plants were classified into 12 families. Families' Amaryllidaceae, Fabaceae, Myrtaceae and Combretaceae recorded (2) species each while all the other families had single species representations (Table 2). Heinrich (2008) reported in his study that, plant families applied in traditional medicine are regarded as families of importance when viewed from a cultural perspective and relating to the effectiveness of the bioactive constituents of member species; so when these factors are combined, tend to have an impact on and determines the choice of medicinal plant for medical applications by the communities.

Table 2: Plants used for the management of diabetes mellitus in Hadejia town

\begin{tabular}{lllll}
\hline No & Plant name & Family & Local name & Part used \\
\hline 1 & Acacia nilotica Lam. & Fabaceae & Bagaruwa & Stembark, Leaves \\
2 & Adansonia digitata Linn. & Malvaceae & Kuka & Seeds \\
3 & Allium sativum Linn. & Amaryllidaceae & Tafarnuwa & Bulb \\
4 & Azadirachta indica A. Juss & Meliaceae & Dogon yaro & Stembark, Leaves \\
5 & Anogeissus leiocarpus DC. & Combretaceae & Marke & Stem \\
6 & Balanite aegyptiaca Linn. & Zygophyllaceae & Aduwa & Stembark, Leaves \\
7 & Citrus medica Linn. & Rutaceae & Lemon tsami & Fruit \\
8 & Eugenia caryophyllata Linn. & Myrtaceae & Kanunfari & Seeds \\
9 & Guiera senegalensis J. F. Gmel & Combretaceae & Sabara & Leaves, Root \\
10 & Mangifera indica Linn. & Anacardiaceae & Mangwaro & Leaves, Stembark \\
11 & Moringa oleifera Lam. & Moringaceae & Zogale & Leaves \\
12 & Parkia biglobosa Jacq. & Fabaceae & Dorawa & Fruit \\
13 & Piliostigma malabaricum Roxb. & Fabaceae & Kalgo & Stembark \\
14 & Psidium guajava Linn. & Myrtaceae & Goba & Leaves \\
15 & Ziziphus mucronata Willd. & Rhamnaceae & Magaryar kura & Leaves \\
\hline
\end{tabular}

Observed among the respondents in the management of diabetes was a common practice of combining one or more medicinal plants, as it is believed that combining the plant species may act 
synergistically in bringing about the desired effects. Tiwari \& Rao, (2002) and Ebong et al. (2008) stated that polyherbal remedies have been known to acts as synergistic and/ antagonistic pharmacological agents to produce desired effects having minimal toxic effects.

The most mentioned medicinal plant part were leaves (Table 3). This finding agrees with the reports of Offiah et al. 2011 and Dike et al. 2012).
This plant part occurring as the most mentioned may be attributed to its easy availability and/ as a result of its high phytochemical content (Khan et al., 2014). Scientifically, photosynthesis actively takes place in the leaves as well as the production of secondary metabolites (Ghorbani, 2005); hence, the diverse bioactive constituents present in leaves may be responsible for its efficacy in the treatment of different ailment (Offiah et al., 2011).

Figure 3: Occurrence of plant parts used for the management of diabetes mellitus in Hadejia

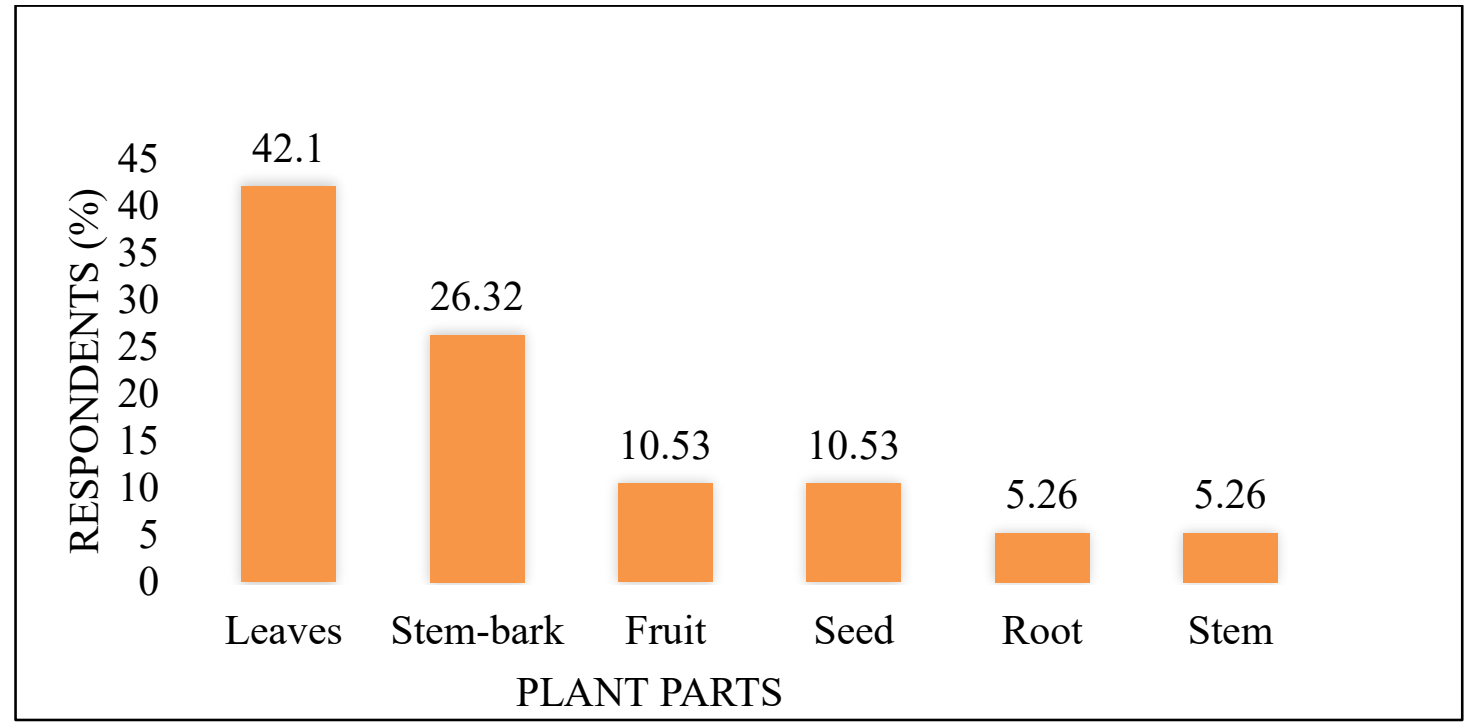

\section{CONCLUSION}

This study was able to provide an insight into the traditional medicine practice with regards to the treatment of diabetes in Hadejia community. It provided data on medicinal plants traditionally employed for managing diabetes in Hadejia. These findings can be used as a basis for further pharmacological investigations in proving their efficacy as antidiabetic agents.

\section{ACKNOWLEDGEMENT}

Dr Mu'azu Kudan's contribution in translating to Hausa and Back translation to English the questionnaires used for the study is duly appreciated. We also appreciate the cooperation of the individual respondents.

\section{REFERENCES}

Addis, G., Abebe, D., Genebo, T., \& Urga, K. (2002). Perceptions and practices of modern and traditional health practitioners about traditional medicine in Shirka District, Arsi Zone, Ethiopia. Ethiopian Journal of Health Development, 16(1), 19-23.

Ajaiyeoba, E. O., Ogbole, O. O., \& Ogundipe, O. O. (2005). Ethnobotanical survey of plants used in the traditional management of viral infections in Ogun State of Nigeria. Editorial Advisory Board $e, 13(1), 64-73$.

Ayeni, E. A., \& Aliyu, N. (2018). Ethnomedicinal survey and documentation of healing river sources among the Yoruba People (Ijesha land), Nigeria. Journal of Complementary Medicine, $8(2), 59-70$. 
Bitrus, D. (2017). Perception and practice of selfmedication among non-clinical students in Niger Delta University, Bayelsa State, Nigeria. The Nigerian Health Journal, 16(4), 205.

Bussmann, R. W., \& Sharon, D. (2006). Traditional medicinal plant use in Loja province, Southern Ecuador. Journal of Ethnobiology and Ethnomedicine, 2(1), 44.

Crump, J. A., Luby, S. P., \& Mintz, E. D. (2004). The global burden of typhoid fever. Bulletin of the World Health Organization, 82, 346-353.

Debella, A., Abebe, D., \& Urga, K. (1999). Traditional medicine in Ethiopia: Perspective and developmental effects. Journal of Ethiopian Medical Practice, 1(2).

Dike, I. P., Obembe, O. O., \& Adebiyi, F. E. (2012). Ethnobotanical survey for potential anti-malarial plants in south-western Nigeria. Journal of Ethnopharmacology, 144(3), 618-626.

Ebong, P. E., Atangwho, I. J., Eyong, E. U., \& Egbung, G. E. (2008). The antidiabetic efficacy of combined extracts from two continental plants: Azadirachta indica (A. Juss) (Neem) and Vernonia amygdalina (Del.) (African bitter leaf). American Journal of Biochemistry and Biotechnology, 4(3), 239-244.

Ghorbani, A. (2005). Studies on pharmaceutical ethnobotany in the region of Turkmen Sahra, north of Iran: (Part 1): General results. Journal of ethnopharmacology, 102(1), 58-68.

Heinrich, M. (2008). Ethnopharmacy and natural product research-Multidisciplinary opportunities for research in the metabolomic age. Phytochemistry Letters, 1(1), 1-5.

International Diabetes Federation (IDF). (2013). IDF Diabetes Atlas 6th Edition. Brussels, Belgium: International Diabetes Federation.

International Diabetes Federation (IDF). (2015). IDF Diabetes Atlas 7th Edition. Brussels, Belgium: International Diabetes Federation.

Jouad, H., Haloui, M., Rhiouani, H., El Hilaly, J., \& Eddouks, M. (2001). Ethnobotanical survey of medicinal plants used for the treatment of diabetes, cardiac and renal diseases in the North centre region of Morocco (Fez-Boulemane). Journal of Ethnopharmacology, 77(2-3), 175182.

Khan, I., AbdElsalam, N. M., Fouad, H., Tariq, A., Ullah, R., \& Adnan, M. (2014). Application of ethnobotanical indices on the use of traditional medicines against common diseases. Evidencebased complementary and alternative medicine.

Mahwasane, S. T., Middleton, L., \& Boaduo, N. (2013). An ethnobotanical survey of indigenous knowledge on medicinal plants used by the traditional healers of the Lwamondo area, Limpopo province, South Africa. South African Journal of Botany, 88, 69-75.

Mesfin, F., Demissew, S., \& Teklehaymanot, T. (2009). An ethnobotanical study of medicinal plants in Wonago Woreda, SNNPR, Ethiopia. Journal of Ethnobiology and Ethnomedicine, 5(1), 28.

Modak, M., Dixit, P., Londhe, J., Ghaskadbi, S., \& Devasagayam, T. P. (2007). Indian herbs and herbal drugs used for the treatment of diabetes. Journal of clinical biochemistry and nutrition, 40(3), 163-173.

Musa, M. S., Abdelrasool, F. E., Elsheikh, E. A., Ahmed, L. A., Mahmoud, A. L. E., \& Yagi, S. M. (2011). Ethnobotanical study of medicinal plants in the Blue Nile State, South-eastern Sudan. Journal of Medicinal Plants Research, 5(17), 4287-4297.

Nwaogu, L. A., Alisi, C. S., Ibegbulem, C. O., \& Igwe, C. U. (2007). Phytochemical and antimicrobial activity of ethanolic extract of Landolphia owariensis leaf. African Journal of Biotechnology, 6(7), 890 - 893.

Offiah, N. V., Makama, S., Elisha, I. L., Makoshi, M. S., Gotep, J. G., Dawurung, C. J., ... \& Shamaki, D. (2011). Ethnobotanical survey of medicinal plants used in the treatment of animal diarrhoea in Plateau State, Nigeria. $B M C$ Veterinary Research, 7(1), 36.

Oyedemi, S. O., Bradley, G., \& Afolayan, A. J. (2009). Ethnobotanical survey of medicinal 
plants used for the management of diabetes mellitus in the Nkonkobe municipality of South Africa.Journal of Medicinal Plants Research, 3(12), 1040-1044.

Rang, H. P., Dale, M. M., Ritter, J. M., \& Moore, P. K. (1991). The endocrine pancreas and the control of blood glucose. In Simmons, B. \& Beasley, S. (Eds), Pharmacology (403-410). Longman Groups Ltd.

Sefidkon, F., Abbasi, K., \& Khaniki, G. B. (2006). Influence of drying and extraction methods on yield and chemical composition of the essential oil of Satureja hortensis. Food Chemistry, 99(1), 19-23.

Tiwari, A. K., \& Rao, J. M. (2002). Diabetes mellitus and multiple therapeutic approaches of phytochemicals: Present status and future prospects. Current Science, 83(1), 30-38.

Wais, M., Nazish, I., Samad, A., Beg, S., Abusufyan, S., Ajaz Ajaj, S., \& Aqil, M. (2012). Herbal drugs for diabetic treatment: an updated review of patents. Recent patents on antiinfective drug discovery, 7(1), 53-59. 